\title{
PENGARUH PROFITABILITAS DAN KEBIJAKAN DIVIDEN TERHADAP NILAI PERUSAHAAN DENGAN STRUKTUR MODAL SEBAGAI PEMEDIASI
}

\author{
Nelly Agustina Musabbihan ${ }^{1}$ \\ Ni Ketut Purnawati ${ }^{2}$ \\ ${ }^{1,2}$ Fakultas Ekonomi dan Bisnis Universitas Udayana, Bali, Indonesia \\ e-mail: nelly91195@gmail.com
}

\begin{abstract}
ABSTRAK
Nilai perusahaan merupakan harga yang bersedia dibayar oleh calon pembeli apabila perusahaan dijual. Nilai perusahaan ini sangat penting karena merupakan cerminan dari kinerja perusahaan yang memperlihatkan prospek perusahaan di masa yang akan datang yang juga merupakan indikator penilaian pasar terhadap perusahaan secara menyeluruh. Tujuan penelitian ini adalah untuk mengetahui pengaruh profitabilitas dan kebijakan dividen terhadap nilai perusahaan dengan struktur modal sebagai pemediasi. Penelitian ini dilakukan di Perusahaan Property dan Real Estate yang terdaftar di BEI. Jumlah sampel yang diambil sebanyak 14 perusahaan dari 42 perusahaan yang terdaftar selama periode 2012-2016 dengan metode purposive sampling. Teknik analisis yang digunakan adalah analisis jalur (path). Berdasarkan hasil analisis ditemukan bahwa profitabilitas berpengaruh positif signifikan terhadap struktur modal, kebijakan dividen berpengaruh positif tidak signifikan terhadap struktur modal, profitabilitas, kebijakan dividen, dan struktur modal berpengaruh positif signifikan terhadap nilai perusahaan, dan struktur modal mampu memediasi antara pengaruh profitabilitas terhadap nilai perusahaan namun tidak dapat memediasi pengaruh kebijakan dividen terhadap nilai perusahaan.
\end{abstract}

Kata Kunci: profitabilitas, kebijakan dividen, struktur modal, nilai perusahaan

\begin{abstract}
Firm value is the price that potential buyers are willing to pay when a company is sold. The value of this company is very important because it is a reflection of the company's performance that shows the prospects of the company in the future which is also a indicator of market valuation of the company as a whole. The purpose of this study is to determine the effect of profitability and dividend policy on firm value with capital structure as mediator. This research was conducted at Property and Real Estate Company listed on BEI. The number of samples taken as many as 14 companies from 42 companies listed during the period 2012-2016 with purposive sampling method. The analysis technique used is path analysis. Based on the results of the analysis found that profitability has a significant positive effect on capital structure, dividend policy has no significant positive effect on capital structure, profitability, dividend policy, and capital structure have a significant positive effect on firm value, and capital structure able to mediate between the effect of profitability on firm value but can not mediate the effect of dividend policy on firm value.
\end{abstract}

Keywords: Profitability, dividend policy, capital structure, firm value 


\section{PENDAHULUAN}

Kondisi ekonomi global umumnya akan terus berkembang mengikuti perkembangan teknologi dan globalisiasi, dalam perdagangan global hal tersebut dapat menimbulkan persaingan usaha. Perusahaan akan terdorong untuk mampu beradaptasi dan melakukan inovasi bisnis untuk tetap dapat bertahan ditengah persaingan usaha dan mendapatkan profit yang optimal. Profitabilitas usaha menjadi hal yang penting untuk dapat meningkatkan kinerja perusahaan. Kinerja perusahaan dapat dilihat dari nilai perusahaan tersebut, dimana nilai perusahaan menjadi tolok ukur bagi konsumen dan investor dalam mempersepsikan keadaan perusahaan.

Nilai perusahaan adalah penting tidak terkecuali bagi perusahaan dalam sektor property dan real estate. Menurut Hamidy dkk. (2015) tren investasi yang berkembang di masyarakat saat ini adalah masyarakat lebih banyak menginvestasikan uang yang dimilikinya dalam bentuk tanah ataupun property. Hal tersebut di dukung dengan statistik pertumbuhan sektor property yang mengalami peningkatan rata-rata $41 \%$ per tahun sebagaimana yang dijelaskan dalam situs resmi www.kemenperin.go.id (2017). Meningkatnya populasi penduduk melebihi ketersediaan tanah, menyebabkan kebutuhan akan ruang bangunan sebagai ruang hunian, perkantoran, maupun fasilitas umum menjadi meningkat, sehingga menjadikan sektor property dan real estate ini sebagai tempat yang diminati bagi para investor untuk berinvestasi. Bagi perusahaan go public investor dapat menilai suatu perusahaan melalui nilai perusahaan yang dicerminkan dari harga sahamnya. 
Nilai perusahaan merupakan harga yang bersedia dibayar oleh calon pembeli apabila perusahaan dijual (Wiagustini, 2013:9). Nilai perusahaan ini sangat penting karena merupakan gambaran dari kinerja perusahaan yang memperlihatkan prospek perusahaan di masa depan yang juga merupakan indikator penilaian pasar terhadap perusahaan secara menyeluruh. Pada penelitian ini nilai perusahaan diukur menggunakan price to book value (PBV) yang merupakan rasio perbandingan harga saham terhadap nilai buku dari perusahaan. Rasio ini digunakan karena dengan rasio ini dapat diketahui apakah tingkat harga sahamnya overvalued ataukah undervalued dari nilai bukunya sehingga dapat menilai tinggi atau rendahnya nilai perusahaan yang tercermin dari harga sahamnya tersebut (Ayu dan Suarjaya, 2017).

Terdapat faktor-faktor yang mempengaruhi nilai perusahaan, seperti yang dinyatakan oleh Sudarma (2004) faktor-faktor yang mempengaruhi nilai perusahaan antara lain, yaitu ukuran perusahaan, pertumbuhan perusahaan, keunikan perusahaan, nilai aktiva, dividen, penghematan pajak, struktur modal, fluktuasi nilai tukar, dan keadaan pasar modal. Menurut Amirya dan Atmini (2007) dan Oktaviani (2008) faktor-faktor yang dapat mempengaruhi nilai perusahaan adalah kebijakan dividen, profitabilitas, pertumbuhan penjualan, dan ukuran perusahaan. Namun, dalam penelitian ini hanya akan dibahas dua faktor yang mempengaruhi nilai perusahaan yaitu profitabilitas dan kebijakan dividen, karena dari penelitian yang sudah dilakukan sebelumnya, masih ditemukan kontroversi dalam pengaruh variabel tersebut terhadap nilai perusahaan baik secara langsung maupun tidak langsung. 
Profitabilitas merupakan salah satu faktor yang berpengaruh terhadap nilai perusahaan. Salah satu indikator penting yang dilihat oleh para investor dalam hal prospek perusahaan di masa yang akan datang adalah dengan melihat sejauh mana pertumbuhan profitabilitas dari sebuah perusahaan (Herawati, 2013). Profitabilitas dikatakan penting karena profitabilitas sebagai indikator dalam mengukur kinerja keuangan perusahaan, sehingga dapat dijadikan acuan untuk menilai perusahaan (Sastrawan, 2016). Profitabilitas dalam penelitian ini, diukur dengan menggunakan Return on Total Assets (ROA) yang mengukur kemampuan dari perusahaan itu sendiri dalam menghasilkan laba dari total aktiva yang digunakannya.

Penelitian yang dilakukan oleh Winarto (2015), Sabrin et al. (2016), dan juga Chen dan Chen (2011), menjelaskan bahwa profitabilitas memiliki pengaruh yang positif terhadap nilai perusahaan. Berbeda halnya dengan hasil yang ditemukan oleh Munawaroh dan Priyadi (2014) dan juga Herawati (2013) yang menyatakan bahwa profitabilitas berpengaruh negatif signifikan terhadap nilai perusahaan.

Nilai perusahaan juga dapat dilihat dari kemampuan perusahaan dalam membagikan dividen (Prastuti dan Sudiartha, 2016). Hal tersebut dikarenakan ketika dividen yang dibagikan tinggi, maka harga sahampun yang merupakan cerminan dari nilai perusahaan cenderung akan meningkat, sehingga nilai perusahaan juga akan tinggi dan begitu juga sebaliknya (Mardiyanthi, 2012). Kebijakan dividen pada dasarnya adalah penentuan besarnya porsi keuntungan yang akan dibagikan kepada pemegang saham (Nofrita, 2013). Kebijakan dividen ini harus dikelola dengan baik karena akan berdampak pada harga saham dan kekayaan pemegang saham (Gill et al., 2010). Perusahaan harus menetapkan rasio 
pembayaran dividen yang tinggi dan menawarkan imbal hasil dividen yang tinggi untuk memaksimalkan harga saham yang mencerminkan nilai perusahaan (Murakefu dan Ouma, 2012). Besar kecilnya dividen yang dibagikan kepada para pemegang saham dapat dilihat dari dividen payout ratio (DPR).

Penelitian dari Rehman (2016), Winarto (2015), dan juga Rizqia dkk. (2013) menyatakan bahwa ada pengaruh positif antara kebijakan dividen terhadap nilai perusahaan. Berbeda halnya dengan penelitian dari Rakhimsyah dan Gunawan (2011) dan juga Hidayati (2010) yang menemukan hasil negatif antara kebijakan dividen terhadap nilai perusahaan.

Berdasarkan hasil penelitian yang telah dilakukan sebelumnya, dimana masih adanya hasil yang tidak konsisten terkait dengan pengaruh profitabilitas dan kebijakan dividen terhadap nilai perusahaan, sehingga diindikasikan adanya variabel lain yang mempengaruhi hubungan diantara kedua variabel tersebut terhadap nilai perusahaan. Dalam penelitian ini struktur modal digunakan sebagai variabel mediasi karena ketika perusahaan memiliki tingkat profit dan pembagian dividen yang tinggi itu akan meningkatkan nilai perusahaan yang di mana peningkatan nilai perusahaan tersebut tidak lepas juga dari peran struktur permodalan perusahaan yang tepat dalam pemilihan sumber dana untuk keberlangsungan perusahaan, karena kedua faktor tersebut sangatlah berhubungan erat dengan sumber dana yang nantinya akan dialokasikan untuk kegiatan perusahaan sehingga dapat meningkatkan nilai perusahaan. Pada penelitian terdahulu juga struktur modal digunakan sebagai variabel mediasi terhadap nilai 
perusahaan seperti penelitian yang dilakukan oleh Anjarwati (2016), Indriyatni (2012), dan juga Wulandari (2013).

Dana yang dibutuhkan bisa datang dari banyak sumber dan dengan bentuk yang berbeda pula (Azhagaiah dan Gavaoury, 2011). Untuk dapat meningkatkan nilai perusahaan, peran struktur modal menjadi salah satu peran yang paling penting karena baik buruknya sruktur modal nantinya akan memberikan pengaruh terhadap nilai perusahaan (Anjarwati dkk., 2016). Struktur modal dalam penelitian ini, diukur dengan menggunakan Debt to Equity Ratio (DER) yang menggambarkan komposisi modal yang digunakan sebagai sumber pendanaan. Berdasarkan penelitian dari Yuanita et al. (2016) dan juga Velnampy dan Niresh (2012) memberikan hasil yang positif signifikan dari pengaruh struktur modal terhadap nilai perusahaan. Berbeda halnya dengan hasil yang ditemukan oleh Hidayati (2010) yang menyatakan struktur modal yang diproksikan dengan DER berhubungan negatif dan tidak signifikan terhadap nilai perusahaan yang diproksikan dengan PBV.

Ada beberapa faktor yang akan mempengaruhi struktur modal. Salah satunya adalah tingkat profitabilitas perusahaan. Profitabilitas pada periode sebelumnya merupakan faktor yang penting dalam menentukan struktur modal, karena dengan memiliki tingkat profitabilitas yang tinggi, maka tingkat laba yang ditahanpun akan besar, sehingga manajemen perusahaan dapat menggunakan laba ditahan untuk memperkuat struktur permodalan sebelum menggunakan utang sebagai alternatif lain. Beberapa penelitian juga mendukung adanya pengaruh antara profitabilitas terhadap struktur modal seperti yang dilakukan oleh Wijaya dan Utama (2014) dan 
juga Maha Dewi dan Sudiartha (2017) yang menyatakan bahwa profitabilitas memiliki pengaruh yang positif dan signifikan terhadap struktur modal. Hasil temuan lainnya oleh Wahyuni dan Suryantini (2014) dan juga Santoso dan Budiarti (2017) menyatakan bahwa profitabilitas memiliki pengaruh negatif terhadap struktur modal.

Selain keputusan pendanaan yang dilakukan berdasarkan dari keadaan profit yang tinggi, kebijakan dividen juga merupakan bagian yang menyatu dengan keputusan pendanaan perusahaan. Menurut Keown (2000:496), rasio pembayaran dividen (DPR) menentukan jumlah laba yang dapat ditahan sebagai sumber pendanaan. Berdasarkan hasil penelitian terdahulu dari Maftukhah (2013), Sumani dan Rachmawati (2012) dan juga Ulfah (2016) yang menunjukkan bahwa adanya pengaruh signifikan dan positif kebijakan dividen terhadap struktur modal perusahaan. Berbeda dengan hasil penelitian yang dilakukan oleh Suhadak (2015) dan juga Laksana (2016) yang menyatakan kebijakan dividen memiliki pengaruh negatif terhadap struktur modal.

Berdasarkan latar belakang di atas yang masih ditemui perbedaan hasil penelitian sebelumnya mengenai pengaruh profitabilitas, kebijakan dividen, dan juga struktur modal terhadap nilai perusahaan, maka penulisan penelitian ini menjadi penting untuk menguji pengaruh profitabilitas dan kebijakan dividen terhadap nilai perusahaan yang dimediasi oleh variabel struktur modal dengan mengambil sampel penelitian pada perusahaan sektor property dan real estate yang terdaftar di Bursa Efek Indonesia (BEI). 
Penelitian ini dilakukan dengan tujuh tujuan diantaranya untuk signifikansi pengaruh profitabilitas terhadap struktur modal; untuk mengetahui signifikansi pengaruh kebijakan dividen terhadap struktur modal; untuk mengetahui signifikansi pengaruh profitabilitas terhadap nilai perusahaan; untuk mengetahui signifikansi pengaruh kebijakan dividen terhadap nilai perusahaan; untuk mengetahui signifikansi pengaruh struktur modal terhadap nilai perusahaan; untuk mengetahui kemampuan struktur modal dalam memediasi pengaruh profitabilitas terhadap nilai perusahaan; serta untuk mengetahui kemampuan struktur modal dalam memediasi pengaruh kebijakan dividen terhadap nilai perusahaan.

Penelitian ini tidak hanya memberikan manfaat yang dapat dirasakan oleh penulis saja, melainkan memberikan manfaat terhadap elemen atau pihak-pihak yang terkait dalam penelitian ini baik secara langsung maupun tidak langsung. Seperti manfaat teoritis dalam penelitian ini diharapkan mampu menambah penelitian-penelitian sebelumnya sehingga dapat menjadi pengembangan maupun penyempurnaan dari penelitian-penelitian sebelumnya. Untuk manfaat praktis dalam penelitian ini diharapkan dapat menjadi bahan pertimbangan maupun rujukan dalam pengambilan solusi bagi investor dan juga perusahaan.

Suatu perusahaan yang memiliki tingkat profitabilitas yang tinggi, cenderung akan membiayai perusahaannya dengan menggunakan modal sendiri yang berasal dari laba ditahan (Santoso dan Budiarti, 2017). Hal ini sesuai dengan pecking order theory menyarankan perusahaan jika membutuhkan pembiayaan maka penghasilan tetap harus menjadi pilihan pertama, kemudian perusahaan dapat memilih pembiayaan utang untuk menjadi pilihan terakhir (Butt S et al., 2013). Berdasarkan 
pernyataan tersebut, maka profitabilitas yang diproksikan dengan ROA memiliki pengaruh yang negatif terhadap struktur modal yang diproksikan dengan DER dan hal ini juga sesuai dengan penelitian dari Rahmiati dkk. (2015), Wahyuni dan Suryantini (2014), dan juga Nadzirah dkk. (2016). Profitabilitas juga dikenal sebagai kinerja keuangan dan terkait erat dengan struktur permodalan perusahaan (Hamid et al., 2015). Berdasarkan pemikiran tersebut, hipotesis yang dapat diajukan dalam penelitian ini adalah:

$\mathrm{H}_{1}$ : Profitabilitas berpengaruh negatif dan signifikan terhadap struktur modal.

Kebijakan dividen adalah keputusan perusahaan dalam menentukan jumlah dividen dan waktu pembagian dividen kepada pemegang saham (Titman et al., 2014:3). Secara tidak langsung, pembagian dividen yang tinggi akan mempengaruhi tingkat penggunaan utang suatu perusahaan karena dana internal sudah dialokasikan untuk pembagian dividen sehingga perusahaan membutuhkan dana lebih untuk keperluan operasional perusahaan yang bisa memicu adanya penambahan utang tersebut (Farisa dan Widati, 2017). Hal ini sesuai dengan penelitian penelitian Maftukhah (2013), Sumani dan Rachmawati (2012) dan juga Ulfah (2016) yang menunjukkan bahwa adanya pengaruh signifikan dan positif antara kebijakan dividen terhadap struktur modal. Berdasarkan pemikiran tersebut, hipotesis yang dapat diajukan dalam penelitian ini adalah:

$\mathrm{H}_{2}$ : Kebijakan dividen berpengaruh positf dan signifikan terhadap struktur modal.

Profitabilitas dari sebuah perusahaan memang biasanya dijadikan salah satu faktor penilaian pasar terhadap perusahaan tersebut. Jika perusahaan memiliki 
profit yang tinggi, maka akan dinilai baik perusahaan itu oleh pasar, dan sebaliknya jika perusahaan memiliki profit yang rendah maka akan dinilai rendah juga oleh pasar karena dirasa tidak akan berjalan baik untuk masa yang akan datang. Berdasarkan penelitian yang pernah dilakukan oleh Wijaya dan Sedana (2015) menyatakan bahwa profitabilitas berpengaruh positif terhadap nilai perushaaan dengan signifikan. Penelitian Wijaya dan Sedana (2015) diperkuat oleh penelitian dari Anjarwati dkk. (2016), Chen dan Chen (2011), Winarto (2015), Rizqia dkk. (2013), Kontesa (2015), Rudangga dan Sudiarta (2016), Kusuma dkk. (2013), Triyono dkk. (2015), serta Ben-Naceur dan Goaied (2002), maka hipotesis yang dapat diajukan dalam penelitian ini adalah:

$\mathrm{H}_{3}$ : Profitabilitas berpengaruh positif dan signifikan terhadap nilai perusahaan.

Kebijakan dividen merupkan salah satu topik yang menarik dalam literatur keuangan (Komrattanapanya dan Suntrauk, 2013). Untuk mencapai nilai perusahaan yang menjanjikan, perusahaan cenderung meningkatkan dividend payout ratio (DPR) (Amirya dan Atmini, 2007). Penelitian yang dilakukan oleh Rehman (2016), Winarto (2015), Rizqia dkk. (2013) dan juga Prastuti dan Sudiartha (2016) memperoleh hasil yang positif dan signifikan pada pengaruh kebijakan dividen terhadap nilai perusahaan, sehingga berdasarkan pemikiran tersebut, hipotesis yang dapat diajukan dalam penelitian ini adalah:

$\mathrm{H}_{4}$ : Kebijakan dividen berpengaruh positif dan signifikan terhadap nilai perusahaan. 
Jika posisi struktur modal berada di bawah titik optimal maka setiap peningkatan hutang juga akan meningkatkan nilai dari perusahaan dan sebaliknya jika posisi struktur modal tersebut berada di atas titik optimal maka setiap peningkatan hutang akan menurunkan nilai perusahaan (Yuanita et al., 2016). Penelitian dari Siahaan dkk. (2014), Hermuningsih (2012), Gayatri dan Mustanda (2014), dan juga Prasetia dkk. (2014) menemukan hasil yang positif antara struktur modal terhadap nilai perusahaan. Hal tersebut sesuai dengan trade off theory, maka berdasarkan pemikiran tersebut, hipotesis yang dapat diajukan dalam penelitian ini adalah:

$\mathrm{H}_{5}$ : Struktur modal berpengaruh positif dan signifikan terhadap nilai perusahaan.

Sebuah perusahaan yang memiliki tingkat profit yang tinggi mengidentifikasikan perusahaan tersebut mempunyai kinerja yang baik, kemudian manajer keuangan dapat mengelola profit tersebut melalui keputusan keuangan yang tepat, salah satunya mengenai keputusan pendanaan (struktur modal) (Khoirianto, 2016). Menurut Khorianto (2016), pada saat keputusan pendanaan yang diambil sudah tepat, maka hal itu dapat menimbulkan sentimen positif dari para investor dan dapat membuat harga saham perusahaan meningkat. Peningkatan harga saham di pasar tersebut menandakan meningkatnya nilai perusahaan. Hal ini sesuai dengan penelitian yang pernah dilakukan oleh Hermuningsih (2012) yang menemukan bahwa struktur modal mampu menjadi varibel mediasi antara pengaruh profitabilitas terhadap nilai perusahaan. Hasil yang sama juga ditemukan oleh Prasetyo dkk. (2017), Anjarwati dkk. (2016), Thaib dan Dewantoro (2017) dan 
Nelly Agustina Musabbihan, Pengaruh Profitbilitas dan ...

juga Khoirianto (2016). Berdasarkan pemikiran tersebut, hipotesis yang dapat diajukan dalam penelitian ini adalah:

$\mathrm{H}_{6}$ : Struktur modal mampu memediasi pengaruh profitabilitas terhadap nilai perusahaan.

Untuk mencapai nilai perusahaan yang menjanjikan, perusahaan cenderung meningkatkan Dividend Payout Ratio (DPR) (Amirya dan Atmini, 2007). Namun peningkatan nilai perusahaan tersebut tidak lepas dari peran struktur modal perusahaan karena ketika pembagian dividen tinggi, maka dapat meningkatkan penggunaan utang sebagai sumber pendanaan eksternal dalam operasi perusahaan karena dana internal sudah dialokasikan untuk pembagian dividen (Khoirianto, 2016). Hal ini didukung oleh penelitian dari Khoirianto (2016), Sugiarto (2011) dan juga Amirya dan Atmini (2007) yang menyatakan bahwa struktur modal mampu memediasi pengaruh antara kebijakan dividen terhadap nilai perusahaan. Berdasarkan penjelasan dan hasil penelitian terdahulu, maka hipotesis yang dapat diajukan dalam penelitian ini adalah:

$\mathrm{H}_{7}$ : Struktur modal mampu memediasi pengaruh kebijakan dividen terhadap nilai perusahaan.

Berdasarkan penjelasan dan rumusan hipotesis di atas, maka kerangka konseptual dari penelitian ini dibuat guna memberikan gambaran hubungan tiap variabel yang disajikan pada Gambar 1 . 




\section{Gambar 1. Kerangka Konseptual}

\section{METODE PENELITIAN}

Lokasi penelitian ini dilakukan di Perusahaan Property dan Real Estate yang terdaftar di Bursa Efek Indonesia (BEI) pada periode 2012-2016. Jenis data yang digunakan dalam penelitian ini adalah data kuantitatif dan kualitatif. Data kuantitatif dalam penelitian ini adalah ROA, DPR, DER, dan juga PBV pada perusahaan property dan real estate yang terdaftar di Bursa Efek Indonesia (BEI) periode 2012-2016, sedangkan data kualitatif dalam penelitian ini adalah gambaran umum mengenai perusahaan property dan real estate. Data ini berasal dari data sekunder, yaitu publikasi laporan keuangan dari seluruh sektor property dan real estate yang terdaftar di Bursa Efek Indonesia (BEI) selama periode 2012-2016.

Populasi dalam penelitian ini adalah seluruh sektor property dan real estate yang terdaftar di Bursa Efek Indonesia (BEI) periode tahun 2012-2016 yang berjumlah 42 perusahaan. Pemilihan sampel dalam penelitian ini menggunakan teknik non-probability sampling berbentuk purposive sampling yang berarti penentuan sampel berdasarkan kriteria-kriteria tertentu dengan hanya menggunakan perusahaan property dan real estate yang memiliki kriteria, yaitu perusahaan property dan real estate yang membagikan dividen secara berturut- 
turut selama periode 2012-2016. Berdasarkan kriteria tersebut, maka jumlah sampel yang digunakan dalam penelitian ini berjumlah 14 perusahaan.

Penelitian ini menggunakan metode pengumpulan data observasi nonpartisipan. Observasi ini dilakukan dengan memperoleh data laporan keuangan dan laporan tahunan dari perusahaan yang termasuk ke dalam sektor property dan real estate yang telah terdaftar di Bursa Efek Indonesia (BEI) pada periode 2012-2016. Penelitian ini menggunakan teknik analisis jalur (path analysis) di dukung dengan metode pemerikasaan.

\section{HASIL DAN PEMBAHASAN}

\section{Deskriptif Variabel Penelitian}

Berdasarkan data dari Bursa Efek Indonesia maka dapat disajikan laporan deskriptif variabel penelitian yaitu Profitabilitas (ROA), Kebijakan Dividen (DPR), Struktur Modal (DER), dan Nilai Perusahaan (PBV), selama periode tahun 20012-2016 adalah sebagai berikut:

\section{Tabel 1}

Deskriptif Variabel Penelitian

\begin{tabular}{|c|c|c|c|c|c|}
\hline \multicolumn{6}{|c|}{ Statistics } \\
\hline & & ROA & DPR & DER & PBV \\
\hline \multirow[t]{2}{*}{$\mathrm{N}$} & Valid & 70 & 70 & 70 & 70 \\
\hline & Missing & 0 & 0 & 0 & 0 \\
\hline \multicolumn{2}{|c|}{ Mean } & 7.7960 & 25.7769 & 91.9184 & 226.5450 \\
\hline \multicolumn{2}{|c|}{ Std. Error of Mean } & .42682 & 6.57460 & 5.68809 & 20.77680 \\
\hline \multicolumn{2}{|c|}{ Median } & 7.4500 & 14.9300 & 89.3450 & 165.5000 \\
\hline \multicolumn{2}{|c|}{ Mode } & $5.32^{\mathrm{a}}$ & $4.23^{\mathrm{a}}$ & $23.63^{\mathrm{a}}$ & 148.00 \\
\hline \multicolumn{2}{|c|}{ Std. Deviation } & 3.57105 & 55.00705 & 47.58997 & 173.83117 \\
\hline \multicolumn{2}{|c|}{ Variance } & 12.752 & 3025.776 & 2264.805 & 30217.275 \\
\hline \multicolumn{2}{|c|}{ Range } & 17.33 & 448.26 & 261.31 & 801.36 \\
\hline \multicolumn{2}{|c|}{ Minimum } & .81 & 4.23 & 23.63 & 28.64 \\
\hline \multicolumn{2}{|c|}{ Maximum } & 18.14 & 452.49 & 284.94 & 830.00 \\
\hline \multicolumn{2}{|c|}{ Sum } & 545.72 & 1804.38 & 6434.29 & 15858.15 \\
\hline
\end{tabular}

a. Multiple modes exist. The smallest value is shown Sumber: Data di olah, 2017 
Hasil Uji Asumsi Klasik

Tabel 2

Hasil Uji Normalitas

\begin{tabular}{lclc}
\hline \multicolumn{1}{c}{ Struktur I } & \multicolumn{2}{c}{ Struktur II } \\
\hline \multicolumn{1}{c}{ Unstandardized Residual } & \multicolumn{2}{c}{ Unstandardized Residual } \\
Kolmogorov-Sminov Z & 1.237 & Kolmogorov-Sminov Z & 1.279 \\
Asymp. Sig. (2-tailed) & .094 & Asymp. Sig. (2-tailed) & .076 \\
\hline Sumber: Data diolah, 2017 & &
\end{tabular}

Nilai koefisien Asymp. Sig. (2-tailed) struktur I dan struktur II lebih besar dari signifikansi yang digunakan yakni sebesar 0,05, maka dapat disimpulkan hasil tersebut menunjukkan bahwa data yang digunakan dalam penelitian adalah berdistribusi normal.

Tabel 3

Hasil Uji Multikoleniaritas

\begin{tabular}{lrrlrr}
\hline \multicolumn{2}{c}{ Struktur I } & & \multicolumn{3}{c}{ Struktur II } \\
\hline Variabel & Tolerance & VIF & Variabel & Tolerance & \multicolumn{1}{c}{ VIF } \\
ROA & .964 & 1.037 & ROA & .809 & 1.236 \\
DPR & .964 & 1.037 & DPR & .947 & 1.056 \\
& & & DER & .837 & 1.195 \\
\hline
\end{tabular}

Sumber: Data diolah, 2017

Berdasarkan hasil pengujian pada Tabel 3 diketahui bahwa tolerance masing-masing variabel bebas lebih dari $10 \%$ atau lebih dari 0,1 . Nilai VIF masingmasing variabel bebas adalah kurang dari 10, sehingga dapat disimpulkan bahwa tidak terdapat multikolinearitas dalam penelitian ini.

\section{Tabel 4}

\section{Hasil Uji Heterokedastisitas}

\begin{tabular}{lrrlrr}
\hline \multicolumn{7}{c}{ Struktur I } & & & Struktur II & \\
\hline \multicolumn{1}{c}{ Model } & \multicolumn{1}{c}{ t } & \multicolumn{1}{c}{ Sig. } & \multicolumn{1}{c}{ Model } & t & Sig. \\
(Constant) & 6.200 & .000 & (Constant) & .310 & .757 \\
ROA & -1.988 & .051 & ROA & 1.937 & .057 \\
DPR & -1.377 & .173 & DPR & 1.360 & .179 \\
& & & DER & .473 & .638 \\
\hline Sumber:
\end{tabular}

Sumber: Data diolah, 2017 
Berdasarkan hasil penelitian pada Tabel 4, tingkat signifikansi masingmasing variabel berada di atas $5 \%$ atau 0,05 sehingga dalam penelitian ini tidak terdapat heterokedastisitas.

Tabel 5

Hasil Uji Autokorelasi

\begin{tabular}{|c|c|c|c|}
\hline \multicolumn{2}{|c|}{ Struktur I } & \multicolumn{2}{|c|}{ Struktur II } \\
\hline Model & Durbin-Watson & Model & Durbin-Watson \\
\hline 1 & 2.244 & 1 & 2.131 \\
\hline
\end{tabular}

Berdasarkan Tabel 5 diketahui nilai DW struktur I dan struktur II lebih besar dari batas atas $\left(\mathrm{d}_{\mathrm{U}}\right)$ dan kurang dari 4 - $\mathrm{d}_{\mathrm{U}}$, maka dapat disimpulkan bahwa dalam model regresi struktur I dan struktur II yang digunakan tidak terjadi autokorelasi atau bebas dari autokorelasi.

\section{Analisis Jalur}

Berdasarkan perhitungan menggunakan teknik analisis jalur dengan bantuan program SPSS dalam pengolahan data, diperoleh hasil seperti di bawah ini.

Tabel 6

\section{Hasil Regresi Struktur I}

\begin{tabular}{|c|c|c|c|c|c|}
\hline \multirow[t]{2}{*}{ Variabel } & \multicolumn{2}{|c|}{ Unstandardized Coefficients } & \multirow{2}{*}{$\begin{array}{c}\begin{array}{c}\text { Standardized } \\
\text { Coefficients }\end{array} \\
\text { Beta }\end{array}$} & \multirow[b]{2}{*}{$\mathrm{t}$} & \multirow[b]{2}{*}{ Sig. } \\
\hline & $B$ & Std. Error & & & \\
\hline (Constant) & 64.779 & 5.775 & & 11.218 & 0.000 \\
\hline $\mathrm{ROA}$ & 2.075 & 0.579 & 0.408 & 3.585 & 0.001 \\
\hline DPR & 0.046 & 0.042 & 0.125 & 1.098 & 0.276 \\
\hline R Square & $=0.163$ & & F Hitung $=6$ & & \\
\hline Adj R Square & $=0.138$ & & Sig. & & \\
\hline
\end{tabular}

Sumber: Data diolah, 2017 


\begin{tabular}{|c|c|c|c|c|c|}
\hline \multirow[t]{2}{*}{ Variabel } & \multicolumn{2}{|c|}{ Unstandardized Coefficients } & $\begin{array}{l}\text { Standardized } \\
\text { Coefficients }\end{array}$ & \multirow[b]{2}{*}{$\mathrm{t}$} & \multirow[b]{2}{*}{ Sig. } \\
\hline & $\mathrm{B}$ & Std. Error & Beta & & \\
\hline (Constant) & -213.622 & 56.954 & & -3.751 & 0.000 \\
\hline ROA & 35.641 & 3.674 & 0.746 & 9.701 & 0.000 \\
\hline DPR & 0.981 & 0.246 & 0.283 & 3.983 & 0.000 \\
\hline DER & 1.555 & 0.710 & 0.166 & 2.190 & 0.032 \\
\hline $\begin{array}{l}\text { R Square } \\
\text { Adj R Square }\end{array}$ & $\begin{array}{l}=0.684 \\
=0.670\end{array}$ & & $\begin{array}{l}\text { F Hitung } \\
\text { Sig. }\end{array}$ & & \\
\hline
\end{tabular}

Berdasarkan data pada Tabel 6 dan 7, maka model struktural analisis jalur dapat dibuat sebagai berikut:

1) Struktur I: $Y_{1}=0.408 X_{1}+0.125 X_{2}+e_{1}$

2) Struktur II: $Y_{2}=0.746 X_{1}+0.283 X_{2}+0.166 Y_{1}+e_{2}$

Berikut juga disediakan hasil perhitungan dari nilai koefisien pengaruh profitabilitas dan kebijakan dividen terhadap nilai perusahaan tanpa adanya variabel mediasi yang disajikan pada Tabel 8 .

Tabel 8

Hasil Regresi Tanpa Variabel Mediasi

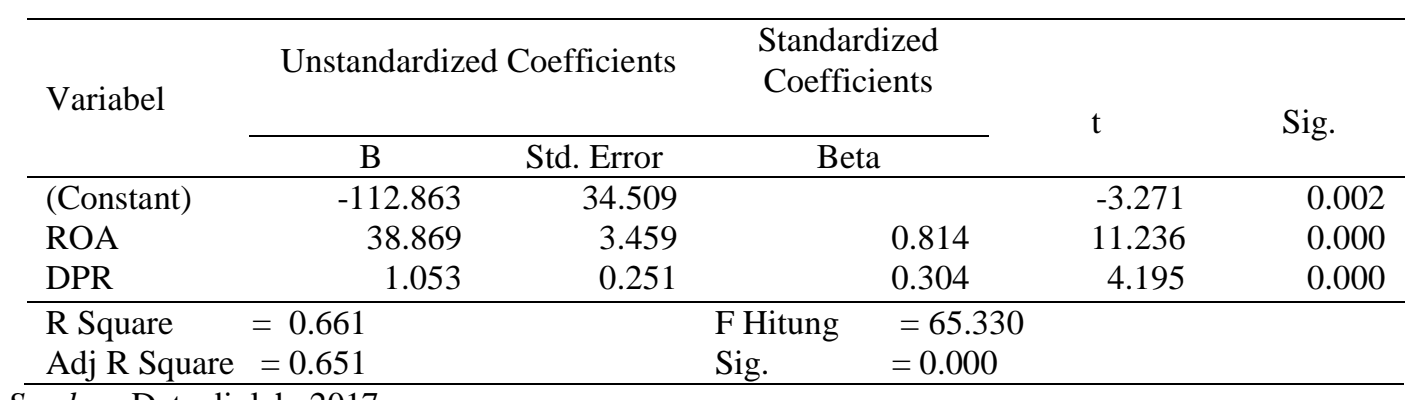

Sumber: Data diolah, 2017

Berdasarkan model struktur I dan struktur II, selanjutnya menghitung standar error model sehingga dapat dibentuk model diagram jalur akhir.

$$
\begin{aligned}
& \mathrm{e}_{\mathrm{i}}=\sqrt{1-R^{2}} \ldots \ldots \ldots \ldots \ldots \ldots \ldots \ldots \ldots \ldots \ldots \ldots \ldots \\
& \mathrm{e}_{1}=\sqrt{1-R^{2}}=\sqrt{1-0.163}=0.915 \\
& \mathrm{e}_{2}=\sqrt{1-R^{2}}=\sqrt{1-0.684}=0.562
\end{aligned}
$$


Berdasarkan Tabel 6, 7, dan 8, dan juga perhitungan nilai standar error, maka di dapatlah model analisis jalur seperti di bawah ini:

\begin{tabular}{|c|c|c|}
\hline $\begin{array}{c}\text { Profitabilitas } \\
\quad\left(\mathbf{X}_{1}\right)\end{array}$ & $\begin{array}{l}\mathrm{Pla}=0.814 \\
\text { Sig. }=0.000\end{array}$ & $\begin{array}{c}\text { Nilai Perusahaan } \\
\left(\mathbf{Y}_{2}\right)\end{array}$ \\
\hline & $\mathrm{P} 1 \mathrm{~b}=0.304$ & \\
\hline $\begin{array}{c}\text { Kebijakan Dividen } \\
\qquad\left(\mathbf{X}_{2}\right)\end{array}$ & & $\begin{array}{c}\text { Nilai Perusahaan } \\
\left(\mathbf{Y}_{2}\right)\end{array}$ \\
\hline
\end{tabular}

Gambar 2. Model Tanpa Melibatkan Variabel Mediasi

Sumber: Data sekunder diolah, 2017

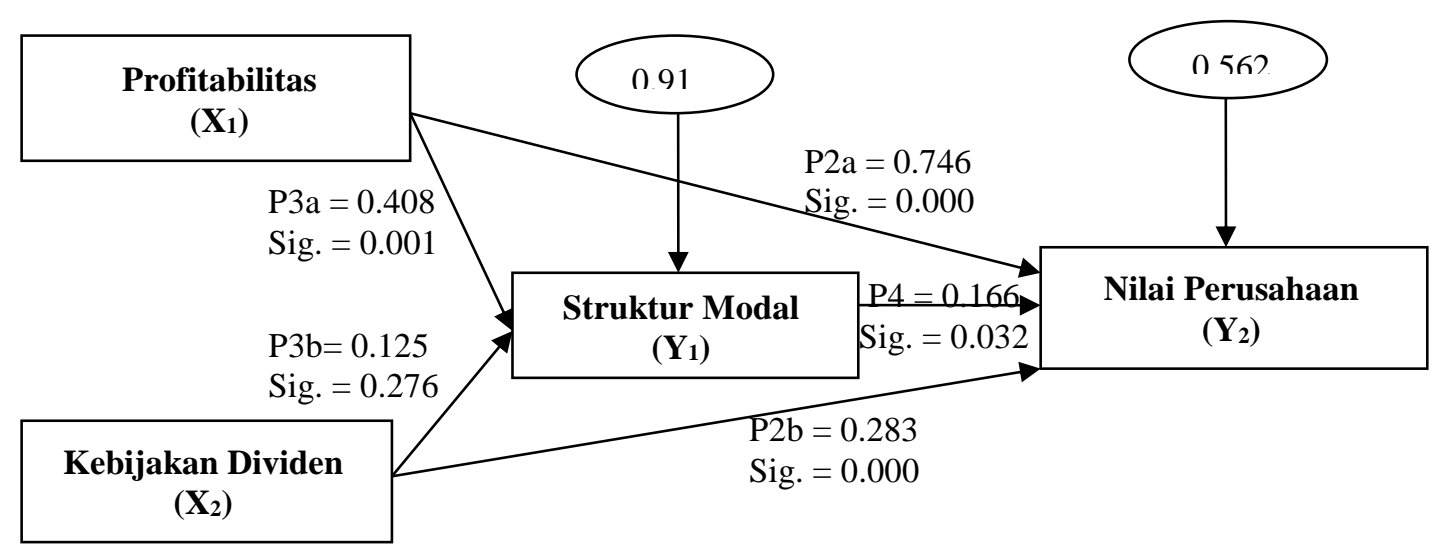

Gambar 3. Validasi Model Analisis Jalur

Sumber: Data sekunder diolah, 2017

Nilai koefisien determinasi total $\left(\mathrm{R}^{2} \mathrm{~m}\right)$ penelitian ini adalah sebesar 0.735 .

Hal ini berarti 73,5 persen variasi dari nilai perusahaan dapat dijelaskan oleh model yang dibentuk, sedangkan sisanya yaitu sebesar 26,5 persen dijelaskan oleh variabel lain di luar model yang dibentuk.

Pengaruh Profitabilitas terhadap Struktur Modal 
Koefisien regresi profitabilitas (X1) sebesar 0,408 dengan nilai signifikansi $0,001<a=0,05$ menunjukkan adanya pengaruh positif dan signifikan antara profitabilitas terhadap struktur modal. Hasil ini menunjukkan bahwa perusahaanperusahaan yang profitable lebih cenderung menggunakan utang untuk operasi perusahaannya karena melakukan ekspansi yang membutuhkan banyak dana untuk mendorong peningkatan laba di masa yang akan datang. Perusahaan cenderung memakai utang dibandingkan dengan mengeluarkan saham, untuk membiayai aktivitas bisnisnya. Hasil penelitian ini sesuai dengan hasil penelitian yang ditemukan oleh Hermuningsih (2012), Indriyatni (2012), Ichwan dan Widyawati (2015), Dewi dan Sudiartha (2017), dan juga Wijaya dan Utama (2014). Namun, bertentangan dengan hasil penelitian dari Rahmiati dkk. (2015), Wahyuni dan Suryantini (2014), dan juga Nadzirah dkk. (2016).

\section{Pengaruh Kebijakan Dividen terhadap Struktur Modal}

Koefisien regresi kebijakan dividen (X2) sebesar 0,125 dengan nilai signifikansi $0,276>a=0,05$ menunjukkan adanya pengaruh positif dan tidak signifikan antara kebijakan dividen terhadap struktur modal. Hal ini sesuai dengan trade-off theory yang menyatakan bahwa perusahaan akan menggunakan utang sampai pada tingkat tertentu dikarenakan adanya penghematan pajak dari tambahan utang tersebut. Kenaikan struktur modal ini disebabkan karena perusahaan menilai manfaat dari penggunaan utang masih lebih besar dibandingkan dengan pengorbanan dari penggunaan utang tersebut, sehingga perusahaan akan menggunakan utang sampai pada tingkat tertentu walaupun dana internal setelah dikurangi dengan pembagian dividen masih dapat dikatakan mencukupi kebutuhan 
operasional perusahaan. Hasil penelitian ini mendukung hasil penelitian dari Farisa dan Widati (2017), Sangeetha dan Sivathaasan (2013), dan juga Lestari dan Hermanto (2015). Namun masih bertentangan dengan hasil penelitian dari Laksana (2016) dan Fauzi (2015).

\section{Pengaruh Profitabilitas terhadap Nilai Perusahaan}

Koefisien regresi profitabilitas (X1) sebesar 0,746 dengan nilai signifikansi $0,000<\mathrm{a}=0,05$ menunjukkan adanya pengaruh positif dan signifikan antara profitabilitas terhadap nilai perusahaan. Sebagian besar investor cenderung menilai perusahaan melalui laba yang dihasilkan oleh perusahaan, karena menganut profit oriented. Berdasarkan hal itu, ketika profitabilitas perusahaan meningkat, maka akan direspon positif oleh investor sehingga nilai perusahaan juga akan meningkat. Hal ini sesuai dengan konsep dari signaling theory yang mengatakan bahwa profitabilitas suatu perusahaan akan menjadi sinyal dari manajemen yang menggambarkan prospek perusahaan. Hasil penelitian ini mendukung penelitian dari Wijaya dan Sedana (2015), Anjarwati dkk. (2016), Chen dan Chen (2011), Winarto (2015), Rizqia dkk. (2013), Kontesa (2015), Rudangga dan Sudiarta (2016), Kusuma dkk. (2013), Triyono dkk. (2015), serta Ben-Naceur dan Goaied (2002). Namun bertentangan dengan hasil penelitian dari Munawaroh dan Priyadi (2014) dan Herawati (2013).

\section{Pengaruh Kebijakan Dividen terhadap Nilai Perusahaan}

Koefisien regresi kebijakan dividen (X2) sebesar 0,283 dengan nilai signifikansi $0,000<a=0,05$ menunjukkan adanya pengaruh positif dan signifikan antara kebijakan dividen terhadap nilai perusahaan. Hasil penelitian ini mendukung 
bird in the hand theory yang menyatakan bahwa para investor lebih menyukai perusahaan yang membagikan dividen karena adanya kepastian tentang return dari investasi yang dilakukan oleh investor serta dapat mengantisipasi risiko ketidakpastian tentang kebangkrutan perusahaan. Selain itu, pembagian dividen risikonya lebih kecil dibandingkan dengan capital gain sehingga pembayaran dividen yang tinggi akan meminimumkan biaya modal yang pada gilirannya akan meningkatkan nilai perusahaan. Hasil penelitian ini mendukung hasil temuan dari Wijaya dan Sedana (2015), Sulong dan Nor (2008), Rehman (2016), Winarto (2015), Rizqia dkk. (2013) dan juga Prastuti dan Sudiartha (2016). Namun bertentangan dengan hasil penelitian dari Hidayati (2010).

\section{Pengaruh Struktur Modal terhadap Nilai Perusahaan}

Koefisien regresi struktur modal (Y1) sebesar 0,166 dengan nilai signifikansi $0,032<\mathrm{a}=0,05$ menunjukkan adanya pengaruh positif antara struktur modal terhadap nilai perusahaan. Hal ini sesuai dengan trade off theory yang menyatakan bahwa jika posisi struktur modal berada di bawah titik optimal maka setiap peningkatan hutang juga akan meningkatkan nilai dari perusahaan dan sebaliknya

jika posisi struktur modal tersebut berada di atas titik optimal maka setiap peningkatan utang akan menurunkan nilai perusahaan (Yuanita et al., 2016). Hasil penelitian ini sesuai dengan hasil penelitian dari Indriyatni (2012), Anjarwati dkk. (2016), Prastuti dan Sudiartha (2016), Siahaan dkk. (2014), Hermuningsih (2012), Gayatri dan Mustanda (2014), dan juga Prasetia dkk. (2014). Namun bertentangan dengan hasil penelitian dari Hidayati (2010). 


\section{Pengaruh Profitabilitas terhadap Nilai Perusahaan dengan Struktur Modal} sebagai Variabel Pemediasi

Berdasarkan hasil yang diperoleh dengan melihat validasi model analisis jalur tanpa melibatkan variabel mediasi dan validasi model analisis jalur dengan variabel mediasi yang mengacu pada konsep analisis variabel mediasi dari Solimun dkk. (2017:91), maka pada penelitian ini struktur modal dapat dikatakan sebagai variabel mediasi sebagian (partial mediation). Hal ini dikarenakan P3a dan P4 signifikan serta P2a juga signifikan, dimana koefisien dari P2a sebesar 0.746 lebih kecil (turun) dari P1a sebesar 0.814 .

Profitabilitas secara positif signifikan memiliki pengaruh langsung terhadap nilai perusahaan, di mana para investor tersebut menilai perusahaan dari tingginya profitabilitas perusahaan sehingga dikatakan memiliki kinerja yang baik yang menyebabkan nilai perusahaan tinggi di mata investor. Namun, peningkatan nilai perusahaan tersebut juga tidak lepas dari peran struktur modal perusahaan karena keputusan struktur modal yang tepat oleh pihak perusahaan guna menjalankan kegiatan perusahaan juga dapat meningkatkan nilai perusahaan. Hasil ini diperkuat oleh temuan dari Khoirianto (2016), Anjarwati dkk. (2016), Mahapsari dan Taman (2013), Hermuningsih (2012), Prasetyo dkk. (2017), dan juga Thaib dan Dewantoro (2017). Namun bertentangan dengan hasil penelitian dari Rubiyani dan Yuniati (2016) dan juga Indriyatni (2012). 
Pengaruh Kebijakan Dividen terhadap Nilai Perusahaan dengan Struktur Modal sebagai Variabel Pemediasi

Mengacu pada konsep analisis variabel mediasi dari Solimun dkk. (2017:91), maka pada penelitian ini struktur modal tidak dapat dikatakan sebagai variabel mediasi dalam pengaruh kebijakan dividen terhadap nilai perusahaan karena pengaruh kebijakan dividen terhadap struktur modal menunjukkan hasil yang tidak signifikan. Apabila tingginya kebijakan dividen diikuti dengan tingginya struktur modal perusahaan hingga melebihi batas optimal maka itu akan menyebabkan penurunan nilai perusahaan. Pada saat struktur modal sudah berada di atas batas optimal, maka hal tersebut menandakan beban bunga yang ditanggung oleh perusahaan sudah di luar batas kemampuan perusahaan. Artinya manfaat yang didapat perusahaan lebih kecil dibandingakan dengan pengorbanan dari penggunaan utang tersebut sehingga menyebabkan kebangkrutan dan nilai perusahaanpun akan turun. Hal tersebutlah yang menyebabkan variabel struktur modal bukan sebagai variabel mediasi. Hasil penelitian ini menolak penelitian dari Khorianto (2016), Sugiarto (2011) dan juga Amirya dan Atmini (2007).

\section{SIMPULAN DAN SARAN}

\section{Simpulan}

Berdasarkan hasil analisis data dan pembahasan penelitian, maka dapat ditarik beberapa kesimpulan, antara lain profitabilitas berpengaruh positif signifikan terhadap struktur modal pada perusahaan sektor property dan real estate yang terdaftar di Bursa Efek Indonesia periode 2012 - 2016; kebijakan dividen berpengaruh positif tidak signifikan terhadap struktur modal pada perusahaan 
sektor property dan real estate yang terdaftar di Bursa Efek Indonesia periode 2012 - 2016; profitabilitas berpengaruh positif signifikan terhadap nilai perusahaan pada perusahaan sektor property dan real estate yang terdaftar di Bursa Efek Indonesia periode 2012 - 2016; kebijakan dividen berpengaruh positif signifikan terhadap nilai perusahaan pada perusahaan sektor property dan real estate yang terdaftar di Bursa Efek Indonesia periode 2012 - 2016; struktur modal berpengaruh positif signifikan terhadap nilai perusahaan pada perusahaan sektor property dan real estate yang terdaftar di Bursa Efek Indonesia periode 2012 - 2016; struktur modal mampu memediasi pengaruh profitabilitas terhadap nilai perusahaan pada perusahaan sektor property dan real estate yang terdaftar di Bursa Efek Indonesia periode 2012 - 2016; struktur modal tidak mampu memediasi pengaruh kebijakan dividen terhadap nilai perusahaan pada perusahaan sektor property dan real estate yang terdaftar di Bursa Efek Indonesia periode 2012 - 2016.

\section{Saran}

Saran yang dapat disampaikan yaitu bagi pihak perusahaan yaitu pihak manajemen perusahaan harus berupaya untuk terus meningkatkan profitabilitas perusahaan dari tahun ke tahun dengan cara menjaga keseimbangan struktur modal agar tingkat utang tetap berada di batas optimal sehingga tidak menyebabkan kebangkrutan. Bagi pihak investor yang ingin melakukan hubungan bisnis dengan perusahaan sektor property dan real estate dengan tujuan mendapatkan keuntungan berdasarkan nilai perusahaan, maka dapat dipertimbangkan faktor-faktor seperti profitabilitas (ROA), kebijakan dividen (DPR), dan juga struktur modal (DER), karena berdasarkan hasil penelitian ini variabel-variabel tersebut memiliki 
pengaruh yang signifikan terhadap nilai perusahaan (PBV). Bagi peneliti selanjutnya dapat mengembangkan penelitian ini di masa mendatang dengan menguji kembali konsistensi hasil penelitian ini dan juga dapat mengembangkan variabel lain yang mempengaruhi nilai perusahaan. Selain itu juga diharapkan pada penelitian selanjutnya dapat menggunakan sampel dari sektor industri selain perusahaan sektor property dan real estate yang mempunyai spesifikasi berbeda, misalnya sektor perbankan sehingga diperoleh perbandingan hasil penelitian.

\section{REFERENSI}

Amirya, Mirna dan Atmini Sari. 2007. Faktor-faktor yang mempengaruhi nilai perusahaan yang dimediasi oleh leverage sebagai variabel intervening: sebuah prsepektif Pecking Order Theory. The 1 Accounting conference faculty of economics Universitas Indonesia, Depok 7-9 November 2007.

Anjarwati, kenti. Mochammad Chabachib dan Irene Rini Demi P. 2016. Pengaruh Profitabilitas, Size, Dan Likuiditas Terhadap Nilai Perusahaan Manufaktur Di Indonesia Dengan Struktur Modal Sebagai Variabel Intervening Studi Empiris Pada Perusahaan Manufaktur Yang Terdaftar Di Bursa Efek Indonesia Tahun 2012-2015. Masters Thesis Manajemen Universitas Diponogoro, Semarang.

Ayu, Dea Putri dan A.A. Gede Suarjaya. 2017. Pengaruh Profitabilitas Terhadap Nilai Perusahaan Dengan Corporate Social Responsibility Sebagai Variabel Mediasi Pada Perusahaan Pertambangan. E-Jurnal Manajemen Unud, 6 (2): 1112-1138.

Azhagaiah, Ramachandran and Candasamy Gavoury. 2011. The Impact of Capital Structure on Profitability with Special Reference to IT Industry in India. Managing Global Transitions, 9 (4): 371-392.

Ben-Naceur, Samy dan Mohamed Goaied. 2002. The Relationship Between Dividend Policy, Financial Structure, Profitability and Firm Value. Applied Financial Economics, 12 (12): 843-849.

Butt S, ZA Khan, B Nafess. 2013. Static Trade-offor Pecking order theory which one suits best to the financial sector. Eviden from Pakistan. European Journal of Business and Management, 5 (23): 131-140. 
Chen, Shun-Yu. Chen, Li-Jun. 2011. Capital Structure Determinants: An empirical Study in Taiwan. African Journal of Business Management, 5 (27): 1097410983.

Dewi, Dewa Ayu Intan Yoga Maha dan Gede Mertha Sudiartha. 2017. Pengaruh Profitabilitas Ukuran Perusahaan, Dan Pertumbuhan Aset Terhadap Struktur Modal dan Nilai Perusahaan. E-Jurnal Manajemen Unud, 6 (4): 2222-2252.

Farisa, Nurul Anggun dan Listyorini Wahyu Widati. 2017. Analisa Profitabilitas, Likuiditas, Pertumbuhan Penjualan, Struktur Aktiva dan Kebijakan Dividen terhadap Struktur Modal. Prosiding Seminar Nasional Multi Disiplin Ilmu \& Call For Papers Unisbank Ke-3 (SENDI_U 3): 640-649.

Fauzi, Nohammad Nur. 2015. Pengaruh Kebijakan Dividen dan Pertumbuhan Perusahaan terhadap Struktur Modal dan Profitabilitas. Jurnal Administrasi Bisnis, 24 (1): 1 -10.

Gayatri, Ni Luh Putu Rassri dan I Ketut Mustanda. 2014. Pengaruh Struktur Modal, Kebijakan Dividen Dan Keputusan Investasi Terhadap Niali Perusahaan. EJurnal Manajemen Universitas Udayana, 3 (6): 1700-1718.

Gill, Amarjit, Nahnum Biger and Rajendra Tibrewala. 2010. Determinants of Dividend Payout Ratios: Evidence from United States. Business Journal, 3: 8-14.

Hamid, Masdiah Abdul. Azizah Abdullah dan Nur Atiqah Kamaruzzaman. 2015. Capital Structure and Profitability in Family and Non-Family Firms: Malaysian evidence. Procedia Economics and Finance. International Accounting And Business Conference 2015, Iabc 2015, 31: 44-55

Hamidy, Rahman Rusdi. I Gusti Bagus Wiksuana, Luh Gede Sri Artini. 2015. Pengaruh Struktur Modal Terhadap Nilai Perusahaan Dengan Profitabilitas Sebagai Variabel Intervening Pada Perusahaan Properti dan Real Estate diBursa Efek Indonesia. E-Jurnal Ekonomi dan Bisnis Universitas Udayana, 4 (10): 665-682.

Herawati, Titin. 2013. Pengaruh Kebijakan Dividen, Kebijakan Hutang dan Profitabilitas Terhadap Nilai Perusahaan. Jurnal Manajemen, 2 (2): 1-18.

Hermuningsih, Sri. 2012. Pengaruh Profitabilitas, Size Terhadap Nilai Perusahaan Dengan Struktur Modal Sebagai Variabel Intervening. Journal Siasat Bisnis, 16 (2): 232-242.

Hidayati, Eva Eko. 2010. Analisis Pengaruh DER, DPR, ROE, dan Size terhadap PBV Perusahaan Manufaktur yang Listing di BEI pweiode 2005-2007. Jurnal Bisnis STRATEGI, 19 (2): 166-174. 
Ichwan, Fith Yuniar dan Dini Widyawati. 2015. Pengaruh Ukuran Perusahaan, Struktur Aktiva dan Profitabilitas Terhadap Struktur Modal. Jurnal Ilmu \& Riset Akuntansi, 4 (6): 1-19.

Indriyatni, Lies. 2012. Analisis Faktor-Faktor yang Mempengaruhi Nilai Perusahaan Dengan Struktur Modal Sebagai Mediasi Pada Perusahaan Development Property yang Terdaftar Di Bursa Efek Indonesia 2007-2010. Fokus Ekonomi, 7 (1): 57-69.

Keown. 2000. Dasar-dasar Manajemen Keuangan, Buku Kedua, Edisi Pertama, Alih Bahasa Chaerul Djakman dan Sulistryatini, Salemba Empat, Jakarta.

Khoirianto, Redy. 2016. Pengaruh Profitabilitas dan Kebijakan Dividen terhadap Nilai Perusahaan dengan Struktur Modal Sebagai Variabel Intervening. Jurnal Ilmiah Ilmu-ilmu Ekonomi, 9 (1): 1-14.

Komrattanapanya, Pornumpai dan Suntrauk, Phassawan. 2013. Fakctors Influencing Dividend Payout in Thailand: A Tobit Regression Analysis. International Journal of Accounting and Financial Reporting, 3 (2): 255-268.

Kontesa, Maria. 2015. Capital Structure, Profitability, And Firm Value. Whats New?. Research Journal of Finance and Accounting, 6 (20): 185-192.

Kusuma, G. I., Suhadak, dan Z. Arifin. 2013. Analisis Pengaruh Profitabilitas (Profitability) dan Tingkat Pertumbuhan (Growth) Terhadap Struktur Modal dan Nilai Perusahaan (Sudi pada Perusahaan Real Estate and Property yang Terdaftar di Bursa Efek Indonesia (BEI) Periode 2007-2011). Jurnal Profit, 7 (2): $1-15$.

Laksana, Intan Frintia. 2016. Pengaruh Kepemilikan Saham, Kebijakan Dividen, Tangibility, Size, dan Profitabilitas Terhadap Struktur Modal. Jurnal Ilmu dan Riset Akuntansi, 5 (4): 1-18.

Lestari, Sisil Ayu dan Suwardi Bambang Hermanto. 2015. Pengaruh Kepemilikan Saham dan Rasio Keuangan terhadap Struktur Modal. Jurnal Ilmu dan Riset Akuntansi, 4 (3): 1-21.

Maftukhah, Ida. 2013. Kepemilikan Manajerial, Kepemilikan Institusional, dan Kinerja Keuaangan Sebagai Penentu Struktur Modal Perusahaan. Jurnal Dinamika Manajemen, 4 (1): 69-81.

Mahapsari, Nunky Rizka dan Abdullah Taman. 2013. Pengaruh Profitabilitas, Struktur Aktiva, dan Pertumbuhan Penjualan terhadap Harga Saham dengan Struktur Modal Sebagai Variabel Intervening Pada Perusahaan Manufaktur di Bursa Efek Indonesia. Jurnal Nominal, 2 (1): 137-158.

Mardiyanthi, Ika Fanindya. 2012. Analisis Pengaruh Profitabilitas, Kebijakan Dividen, Kebijakan Utang, Dan Kepemilikan manajerial Terhadap Nilai 
Perusahaan (Studi Empiris pada Perusahaan Manufaktur yang Terdaftar di Bursa Efek Indonesia Periode 2009-2011). Skripsi Fakultas Ekonomika Dan Bisnis Universitas Diponegoro, Semarang.

Munawaroh, Aisyatul. Priyadi, Maswar Patuh. 2014. Pengaruh Profitabilitas Terhadap Nilai Perusahaan dengan Corporate Socia; Responsibility Sebagai Variabel Moderating. Jurnal Ilmu dan Riset Akuntansi, 3 (4): 1-17.

Murakefu, Timothy Mahalang'ang'a dan Ouma Ochuodho Peter. 2012. The Relationship Between Dividend Payout And Firm Performance: A Study Of Listed Companies In Kenya. European Scientific Journal, 8 (9): 199-215.

Nadzirah. Fridayana Yudiaatmaja dan Wayan Cipta. 2016. Pengaruh Ukuran Perusahaan dan Profitabilitas terhadap Struktur Modal. E-Journal Bisma Universitas Pendidikan Ganesha, 4 (1): 1-13.

Nofrita, Ria. 2013. Pengaruh Profitabilitas Terhadap Nilai Perusahaan dengan Kebijakan Dividen sebagai Variabel Intervening (Studi Empiris Pada Perusahaan Manufaktur Yang Terdaftar di BEI). Jurnal Akuntansi, 1 (1): 123.

Oktaviani, Weri Ningsih. 2008. Pengaruh Kebijakan Deviden, Profitabilitas, Pertumbuhan Penjualan, Ukuran Perusahaan Terhadap Nilai Perusahaan Dengan Leverage Keuangan Sebagai Variabel Intervening. Skripsi Akuntansi Fakultas Ekonomi Universitas Bung Hatta

Prasetia, Ta'dir Eko, Perengkuan Tommy, dan Ivone S. Saerang. 2014. Pengaruh Struktur Modal, Ukuran Perusahaan, Risiko Bisnis Terhadap Nilai Perusahaan Terhadap Nilai Perusahaan Pada Perusahaan Otomotif Di BEI. Jurnal EMBA, 2 (2): 879-889.

Prastuti, Ni Kadek Rai dan I Gede Merta Sudiartha. 2016. Pengaruh Struktur Modal, Kebijakan Deviden, dan Ukuran Perusahaan Terhadap Nilai Perusahaan Pada Perusahaan Manufaktur. E-Jurnal Manajemen Unud, 5 (3): 1572-1598.

Prasetyo, Fajar Eko. Fifi Swandari dan Dian MAsita Dewi. 2017. Pengaruh Profitabilitas, Pajak dan Growth Opportunity Terhadap Nilai Perusahaan Melalui Struktur Modal Sebagai Variabel Intervening. Jurnal Wawasan Manajemen, 5 (1): 51-62.

Rahmiati. Abel Tasman dan Yulira Melda. 2015. Pengaruh Profitabilitas dan Ukuran Perusahaan Terhadap Struktur Modal Perusahaan Property dan Real Estate Yang Terdaftar di Bursa Efek Indonesia Tahun 2010-2013. Seminar Nasional Ekonomi Manajemen dan Akuntansi (SNEMA) Fakultas Ekonomi Universitas Negeri Padang. 
Rakhimsyah, Leli Amnah. Gunawan, Barbara. 2011. Pengaruh Keputusan Investasi, Keputusan Pendanaan, Kebijakan Dividend an Tingkat Suku Bunga Terhadap Nilai Perusahaan. Jurnal Investasi, 7 (1): 31-45.

Rehman, Obaid Ur. 2016. Impact of Capital Structure and Dividend Policy on Firm Value. Journal of Poverty, Investment and Development. An International Peer-reviewed Journal, 21: 40-57.

Rizqia, Dwita Ayu, Siti Aisjah and Sumiati. 2013. Effect of Managerial Ownership, Financial Leverage, Profitability, Firm Size, and Investment Opportunity on Dividend Policy and Firm Value. Journal of Finance and Accounting, 4 (1): 120-130.

Rubiyani, Debi dan Tri Yuniati. 2016. Pengaruh Profitabilitas Terhadap Firm Value Dengan Capital Structure Sebagai Variabel Intervening. Jurnal Ilmu dan Riset Manajemen, 5 (4): 1-16.

Rudangga, I Gusti Ngurah Gede dan Gede Merta Sudiarta. 2016. Pengaruh Ukuran Perusahaan, Leverage, Dan Profitabilitas Terhadap Nilai Perusahaan. EJurnal Manajemen Unud, 5 (7): 4394-4422.

Sabrin. Buyung Sarita. Dedy Takdir. S, Sujono. 2016. The Effect of Profitability on Firm Value inManufacturing Company at Indonesia Stock Exchange. The International Journal Of Engineering And Science (IJES), 5 (10): 81-89.

Sangeetha dan Sivathaasan. 2013. Factors Determining Capital Structure: A Case Study Of Listed Companies in Sri Lanka. Research Journal of Finance and Accounting, 4 (6): 236-247.

Santoso, Defvi Lavinia dan Anindhyta Budiarti. 2017. Faktor-faktor yang Mempengaruhi Struktur Modal Pada Perusahaan Food and Beverages. Jurnal Ilmu dan Riset Manajemen, 6 (2): 1-16.

Sastrawan, I Made Dwi. 2016. Pengaruh Langsung Dan Tidak Langsung Good Corporate Goverrnance Terhadap Pengungkapan Tanggung Jawab Sosial Perusahaan. E-Jurnal Akuntansi Universitas Udayana, 14 (11): 1-32.

Siahaan, Uke Marius. Suhadak. Siti Ragil Handayani dan Solimun. 2014. The Influence of Company Size and Capital Structure Towards Liquidity, Corporate Performance and Firm Value, for Large and Small Group Companies. European Journal of Business and Management, 6 (18): 148156.

Solimun. Adji Achmad Rinaldo Fernandes dan Nurjannah. 2017. Metode Statistika Multivariat Pemodelan Persamaan Struktural (SEM) Pendekatan WarpPLS. Malang: UB Press 
Sudarma, Made. 2004. Pengaruh Struktur Kepemilikan Saham, Faktor Internal dan Faktor Eksternal Terhadap Struktur Modal dan Nilai Perusahaan. Disertasi Program Pascasarjana Universitas Brawijaya, Malang

Sugiarto, Melanie. 2011. Pengaruh Struktur Kepemilikan dan Kebijakan Dividen terhadap Nilai Perusahaan dengan Kebijakan Hutang Sebagai Intervening. Jurnal Akuntansi Kontemporer, 3 (1): 1-25.

Suhadak, Mohammad Nur Fauzi. 2015. Pengaruh Kebijakan Dividen dan Pertumbuhan Perusahaan Terhadap Struktur Modal dan Profitabilitas. Jurnal Administrasi Bisnis (JAB), 24 (1): 1-10.

Sulong, Zunaidah dan Fauzias Mat Nor. 2008. Dividends, Ownership Structure and Board Governance on Firm Value: Empirical Evidence From Malaysian Listed Firms. Malaysian Accounting Review, 7 (2): 55-94.

Sumani dan Lia Rachmawati. 2012. Analisis Struktur Modal Dan Beberapa Faktor Yang Mempengaruhinya Pada Perusahaan Manufaktur Di Bursa Efek Indonesia. Jurnal EMAS, 6 (1): 30-41.

Thaib, Ilham dan Acong Dewantoro. 2017. Pengaruh Profitabilitas dan Likuiditas Terhadap Nilai Perusahaan dengan Struktur Modal Sebagai Variabel Intervening. Jurnal Riset Perbankan Manajemen dan Akuntansi, 1 (1): 25-44.

Titman, Sheridan J, Arthur J. Keown, dan John D. Martin. 2014. Financial Management: Principles and Applications. Edisi ke-12. USA: Pearson Education.

Triyono, K. R. dan Arifati, R. 2015. Pengaruh Kebijakan Dividen, Struktur Kepemilikan, Kebijakan Hutang, Profitabilitas Dan Ukuran Perusahaan Terhadap Nilai Perusahaan Pada Perusahaan Manufaktur Di Bursa Efek Indonesia. Journal Of Accounting, 1 (1): 1-13.

Ulfah, Azmia. 2016. Faktor-Faktor Yang Mempengaruhi Kebijakan Dividen dan Dampak Kebijakan Dividen Terhadap Struktur Modal Bank BUMN Periode 2005-2014. Perbanas Institute Journals, 2 (1): 1-16.

Velnampy, T dan J.A. Niresh. 2012. The Relationship between Capital Structure and Profitability. Global Journal of Management and Business Research, 12 (13): 66-74.

Wahyuni, Indah Ayu Tri dan Ni Putu Santi Suryantini. 2014. Pengaruh Ukuran Perushaaan, Profitabilitas dan Penghematan Pajak Terhadap Struktur Modal. E-Jurnal Manajemen Universitas udayana, 3 (5): 1457-1470.

Wiagustini, Ni Luh Putu. 2013. Dasar-dasar Manajemen Keuangan. Denpasar: Udayana University Press 
Wijaya, Bayu Irfandi dan I B Panji Sedana. 2015. Pengaruh Profitabilitas Terhadap Nilai Perushaan (Kebijakan Dividen Dan Kesempatan Investasi Sebagai Variabel Mediasi). E-Jurnal Manajemen Unud, 4 (12): 4477-4500.

Wijaya, I Putu Andre Sucita dan I Made Karya Utama. 2014. Pengaruh Profitabilitas, Struktur Aset dan Pertumbuhan Penjualan Terhadap Struktur Modal Serta Harga Saham. E-Jurnal Akuntansi Universitas Udayana, 6 (3): 514-530.

Winarto, Jacinta. 2015. The Determinants of Manufacturer Firm Value in Indonesia Stock Exchange. International Journal of Information, Business and Management, 7 (4): 323-349.

Wulandari, Dwi Retno. 2013. Pengaruh Profitabilitas, Operating Leverage, Likuiditas Terhadap Nilai Perusahaan Dnegan Struktur Modal Sebagai Intervening. Accounting Analysis Journal, 2 (4): 455-463.

www.kemenperin.com (Diakses pada tanggal 8 Mei 2017)

Laporan Keuangan Perusahaan Sektor Property dan Real Estate yang Terdaftar di Bursa Efek Indonesia Periode 2012 - 2016 www.idx.go.id (Diakses pada Agustus 2017).

Yuanita. Missy. Budianto. Slamet Riyadi. 2016. Influence Of Capital Structure, Size And Growth On Profitability And Corporate Value. International Journal of Business and Finance Management Research, 4: 80-101. 